\title{
Kepemilikan Manajerial Sebagai Pemoderasi Pengaruh Capital Intensity Pada Agresivitas Pajak
}

\author{
Ni Putu Budiadnyani ${ }^{1}$ \\ Fakultas Ekonomi dan Bisnis \\ Universitas Pendidikan Nasional, Indonesia
}

Surel : putubudiadnyani@undiknas.ac.id

\begin{abstract}
ABSTRAK
Penelitian ini menguji pengaruh capital intensity pada agresivitas pajak serta menguji kemampuan kepemilikan manajerial sebagai variabel pemoderasi pada hubungan pengaruh capital intensity pada agresivitas pajak. Jumlah sampel yang dianalisis sebanyak 34 sampel perusahaan manufaktur sektor barang konsumsi yang terdaftar di Bursa Efek Indonesia (BEI) selama lima tahun. Metode penentuan sampel adalah nonprobability dengan teknik purposive sampling. Teknik analisis yang digunakan adalah regresi linear dan Moderated Regression Analysis (MRA). Hasil analisis menunjukkan bahwa capital intensity berpengaruh positif pada agresivitas pajak. Kepemilikan manajerial memperlemah pengaruh capital intensity pada agresivitas pajak.
\end{abstract}

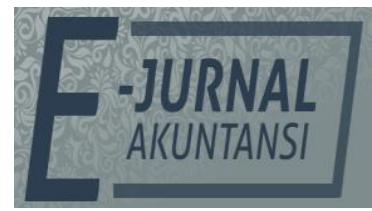

e-ISSN 2302-8556

Vol. 30 No. 9

Denpasar, September 2020 Hal. 2244-2256

DOI:

10.24843/EJA.2020.v30.i09.p06

Kata Kunci: Capital Intensity; Agresivitas; Kepemilikan Manajerial.

\section{Managerial Ownership As A Moderating Effect of Capital Intensity On Tax Aggressiveness}

\section{ABSTRACT}

This study examines the effect of capital intensity on tax aggressiveness and tests the ability of managerial ownership as a moderating variable on the relationship of the effect of capital intensity on tax aggressiveness. The number of samples analyzed was 34 samples of manufacturing companies in the consumer goods sector which were listed on the Indonesia Stock Exchange (IDX) for five years. The sampling method is nonprobability with a purposive sampling technique. The analysis technique used is linear regression and Moderated Regression Analysis (MRA). The analysis shows that capital intensity has a positive effect on tax aggressiveness. Managerial ownership weakens the effect of capital intensity on tax aggressiveness.
PENGUTIPAN:

Budiadnyani, N. P. (2020).

Kepemilikan Manajerial Sebagai Pemoderasi

Pengaruh Capital Intensity

Pada Agresivitas Pajak. EJurnal Akuntansi, 30(9), 2244-

2256

RIWAYAT ARTIKEL:

Artikel Masuk:

7 Juli 2020

Artikel Diterima: 26 Agustus 2020

Keywords: Capital Intensity; Aggressiveness; Managerial Ownership.

Artikel dapat diakses : https://ojs.unud.ac.id/index.php/Akuntansi/index 


\section{PENDAHULUAN}

Penerimaan negara dapat bersumber dari berbagai sektor, baik sektor internal maupun eksternal. Salah satu sumber penerimaan negera dari sektor internal adalah pajak. Penerimaan negara yang berasal dari pajak hingga saat ini masih menjadi penerimaan terbesar bagi Anggaran Pendapatan dan Belanja Negara (APBN). Oleh karena itu, pajak menjadi fokus pemerintah karena pajak menjadi tumpuan terbesar di dalam Anggaran Pendapataan dan Belanja Negara (APBN). Pajak adalah kontribusi wajib kepada negara yang terutang oleh orang pribadi atau badan yang bersifat memaksa berdasarkan undang-undang, dengan tidak mendapatkan imbalan secara langsung dan digunakan untuk keperluan negara bagi sebesar-besarnya kemakmuran rakyat (Pasal 1, UU No. 16 Tahun 2009).

Kontribusi pajak bagi Negara sangat diperlukan untuk pengembangan dan pembangunan di suatu Negara dan kemakmuran rakyat, khususnya di Indonesia yang masih merupakan Negara berkembang (Lestari et al., 2019). Kemakmuran rakyat dapat diwujudkan melalui kesejahteraan suatu bangsa dengan perbaikan pada sektor ekonomi, pembangunan infrasrturktur yang merata di seluruh wilayah serta mewujudkan keamanan nasional. Berfokus pada perbaikan di sektor ekonomi yang akan menunjang hajat hidup masyarakat Indonesia, Presiden Joko Widodo memiliki upaya untuk menuju ekonomi Indonesia yang berdikari melalui salah satu program yaitu berkomitmen untuk membangun kapasitas fiskal negara melalui penilaian kinerja penerimaan sektor perpajakan dan diiringan dengan peningkatan potensi pajak di Indonesia. Salah satu target Presiden Joko Widodo berkenaan dengan perpajakan adalah dengan tercapainya tax ratio sebesar 16\% pada tahun 2019 (Adhari \& Sukartha, 2017).

Tax ratio merupakan salah satu indikator yang dapat menilai dan mengukur kinerja penerimaan pajak. Tax ratio ialah perbandingan atau persentase penerimaan pajak terhadap Produk Domestik Bruto (PDB). Rasio ini menyatakan jumlah pajak yang dikumpulkan pada suatu masa berbanding dengan pendapatan nasional atau PDB di masa yang sama (Lestari et al., 2019). Hingga tahun 2019, tax ratio Indonesia belum mencapai 16\% dari tahun 2015 hingga tahun 2019 tax ratio Indonesia berkutat pada angka 10\% hingga 12\%. Berikut capaian tax ratio Indonesia sepuluh tahun terakhir.

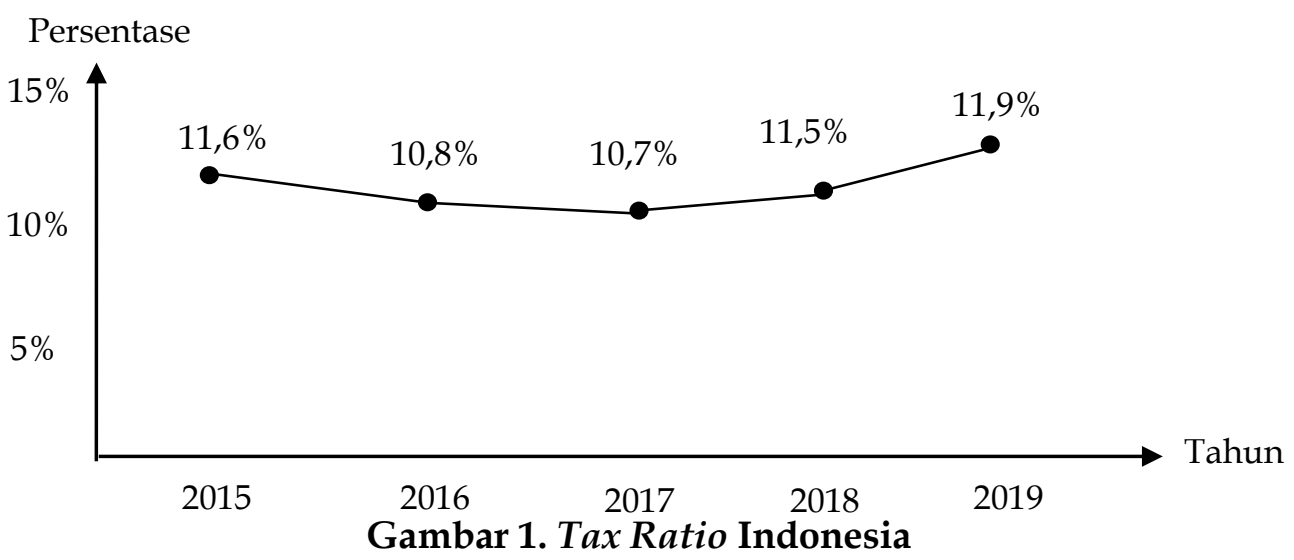

Sumber: Kementerian Keuangan Republik Indonesia, 2019

Selain, tax ratio yang belum mencapai target di tahun 2019. Relasiasi penerimaan pajak selama tiga tahun terakhir tidak mencapai target yang telah 
ditentukan. Berikut target dan capaian penerimaan pajak selama tiga tahun terakhir.

Tabel 1. Realisasi dan Target Penerimaan Pajak Tahun 2017-2019

\begin{tabular}{lccc}
\hline \multicolumn{1}{c}{ Keterangan } & Tahun 2017 & Tahun 2018 & Tahun 2019 \\
\hline Target (Rp) & $1.283,57$ Triliun & $1.424,00$ Trliun & $1.577,56$ Triliun \\
Realisasi (Rp) & $1.151,03$ Triliun & $1.315,51$ Triliun & $1.322,06$ Triliun \\
Persentase & $89,67 \%$ & $92,23 \%$ & $84,44 \%$ \\
\hline
\end{tabular}

Sumber: Kementerian Keuangan Republik Indonesia, 2019

Meskipun kontribusi pajak untuk penerimaan negara merupakan yang terbesar, realisasi penerimaan pajak tahun 2017 sampai dengan tahun 2019 masih di bawah target yang ditetapkan. Realisasi penerimaan pajak yang tidak mencapai target yang telah ditentukan dan tax ratio Indonesia yang menurun menunjukkan adanya keagresivitasan wajib pajak terhadap pajak (Lestari et al., 2019).

Agresivitas pajak menjadi salah satu indikator yang dipergunakan untuk melihat usaha penghindaran pajak oleh wajib pajak. Agresivitas pajak dapat dilakukan melalui mekanisme yang digolongkan tax evasion atau tax avoidance (Frank et al., 2009). Pajak merupakan salah satu komponen beban yang dapat mengurangi laba perusahaan. Tindakan agresif pajak merupakan suatu tindakan yang bertujuan untuk menurunkan laba kena pajak melalui perencanaan pajak baik menggunakan cara yang tergolong atau tidak tergolong tax evasion (Sari \& Martani, 2010).

Pajak merupakan salah satu hal penting dalam pengambilan keputusan (Lanis \& Richardson, 2011). Teori akuntansi positif memaparkan perilaku manajemen perusahaan terkait dengan pembuatan laporan keuangan. Teori ini dilandaskan pada stakeholder, shareholder, fiscus bersifat rasional, serta berupaya memaksimalkan fungsi mereka yang akan berhubungan langsung juga pada kompensasi yang diterima, dan kesejahteraan yang diterima. Penggunaan dari kebijakan akuntansi tersebut tergantung pada relatif biaya, dan manfaat dari prosedur yang dipilih guna memaksimalkan fungsi mereka (Andhari \& Sukartha, 2017). Keputusan manajerial yang menginginkan meminimalkan biaya pajak perusahaan dilakukan melalui tindakan agresif pajak yang semakin marak dilakukan oleh perusahaan-perusahaan di dunia. Besarnya pajak yang harus disetorkan ke kas negara tergantung dari besarnya jumlah laba yang didapat perusahaan selama satu tahun. Pembayaran pajak yang sesuai dengan ketentuan tentunya akan bertentangan dengan tujuan utama perusahaan, yaitu memaksimalkan keuntungan atau laba, sehingga perusahaan berusaha untuk meminimalkan biaya pajak yang ditanggungnya (Indradi, 2018).

Kasus agresivitas pajak banyak ditemui oleh pihak berwenang dalam bentuk penghindaran pajak diberbagai sektor usaha dan ekonomi, tidak terkecuali sektor manufaktur, khususnya barang konsumsi. PT Coca Cola Indonesia yang dituduh melakukan tindakan penghindaran pajak sebesar Rp 49,24 miliar. Hasil penelusuran yang dilakukan oleh Direktorat Jenderal Pajak menemukan bahwa adanya pembengkakan biaya yang mengakibatkan penghasilan kena pajak berkurang secara otomatis beban pajak PT Coca Cola juga akan mengecil (Kandaka \& Pratiwi, 2019). Kasus tersebut membuktikan bahwa ada perusahaan yang berusaha untuk melakukan agresivitas pajak untuk 
memanipulasi laba fiskal. Beberapa cara yang kerap kali dipergunakan untuk melakukan tindakan agresivitas pajak, salah satunya adalah berinvestasi pada aset tetap (capital intensity) (Andhari \& Sukartha, 2017).

Capital intensity yang merupakan investasi perusahaan pada aset tetap merupakan salah satu aset yang digunakan oleh perusahaan untuk berproduksi dan mendapatkan laba. Investasi perusahaan pada aset tetap akan menyebabkan adanya beban depresiasi dari aset tetap yang diinvestasikan. Besarnya beban depresiasi untuk aset tetap diperaturan perpajakan Indonesia beraneka ragam tergantung dari klasifikasi aset tetap tersebut (Andhari \& Sukartha, 2017). Menurut Hanum \& Zulaikha (2013), biaya depresiasi dapat dikurangkan dari penghasilan dalam menghitung pajak, maka semakin besar aset tetap yang dimiliki perusahaan mengakibatkan depresiasi yang besar juga sehingga mengakibatkan jumlah penghasilan kena pajak dan ETR nya berkurang.

Hasil penelitian oleh Andhari \& Sukartha (2017) menyatakan bahwa capital intensity berpengaruh positif pada agresivitas pajak perusahaan. Hasil penelitian Putri \& Lautania (2016) juga menemukan bahwa capital intensity berpengaruh positif signifikan terhadap tarif pajak efektif. Namun berbeda dengan hasil penelitian Lestari et al., (2019) yang menyatakan bahwa capital intensity berpengaruh negatif terhadap agresivitas pajak. Hasil penelitian berbeda diperoleh Nugraha \& Meiranto (2015) serta Ardyansah \& Zulaikha, (2014) menemukan bahwa capital intensity berpengaruh negatif tidak signifikan terhadap agresivitas pajak. Hasil penelitian Indradi (2018) menyatakan bahwa capital intensity tidak berpengaruh signifikan terhadap agresivitas pajak.

Hasil penelitian sebelumnya bervariasi, sehingga memberi peluang untuk dilakukan penelitian lanjutan baik yang bersifat pengulangan maupun pengembangan. Perbedaan penelitian ini dari penelitian sebelumnya terletak pada penambahan variabel pemoderasi yaitu kepemilikan manajerial dalam kaitan hubungan pengaruh capital intensity pada agresivitas pajak. Adanya kepemilikan manajerial diharapkan akan mampu mengurangi tindakan agresif manajemen dalam meminimalkan meminimalkan biaya pajak yang ditanggung oleh perusahaan. Kepemilikan oleh manajemen dirasa mampu meningkatkan rasa memiliki oleh manajemen, sehingga akan meningkatkan perhatian pada masa depan perusahaan.

Ada konflik kepentingan yang di antara pemegang saham (prinsipal) dengan manajer perusahaan (agen), membuat adanya kemungkinan bahwa manajer dapat melakukan tindakan yang dapat meningkatkan kesejahteraannya, yaitu dengan cara mengorbankan beberapa kepentingan pemegang saham. Salah satu metode yang dapat digunakan untuk menghilangkan permasalahan agensi yang dapat menyelaraskan kepentingan antara manajemen dengan pemegang saham, yaitu dengan meningkatkan kepemilikan saham oleh manajer pada perusahaan (Hartadinata \& Tjaraka, 2013) dan (Atari et al., 2016). Kepemilikan manajerial merupakan kepemilikan saham oleh pihak manajemen, dimana pihak manajemen secara aktif ikut terlibat dalam pengambilan keputusan perusahaan (Fadhila et al., 2017). Semakin besar proporsi kepemilikan saham manajerial di dalam perusahaan, maka pihak manajemen cenderung lebih giat untuk memperhatikan kepentingan pemegang saham dan membuat risiko perusahaan semakin kecil. Hal ini dikarenakan apabila terdapat keputusan yang salah, 
manajemen baik secara langsung maupun tidak langsung akan menanggung konsekuensinya dengan saham saham yang diinvestasikan di dalam perusahaan (Wijaya \& Saebani, 2019).

Teori akuntansi positif memaparkan perilaku manajemen perusahaan dalam pembuatan laporan keuangan terkait penggunaan dari kebijakan akuntansi tergantung pada relatif biaya, dan manfaat dari prosedur yang dipilih guna memaksimalkan fungsi mereka (Andhari \& Sukartha, 2017). Besarnya pajak yang harus disetorkan ke kas negara tergantung dari besarnya jumlah laba yang didapat perusahaan selama satu tahun. Pembayaran pajak yang sesuai dengan ketentuan tentunya akan bertentangan dengan tujuan utama perusahaan, yaitu memaksimalkan keuntungan atau laba, sehingga perusahaan berusaha untuk meminimalkan biaya pajak yang ditanggungnya (Indradi, 2018). Beberapa cara yang kerap kali dipergunakan untuk melakukan tindakan agresivitas pajak, salah satunya adalah berinvestasi pada aset tetap (capital intensity) (Andhari \& Sukartha, 2017)

Capital intensity yang merupakan investasi perusahaan pada aset tetap merupakan salah satu aset yang digunakan oleh perusahaan untuk berproduksi dan mendapatkan laba. Investasi perusahaan pada aset tetap akan menyebabkan adanya beban depresiasi dari aset tetap yang diinvestasikan. Besarnya beban depresiasi untuk aset tetap diperaturan perpajakan Indonesia beraneka ragam tergantung dari klasifikasi aset tetap tersebut (Andhari \& Sukartha, 2017). Menurut Hanum \& Zulaikha (2013), biaya depresiasi dapat dikurangkan dari penghasilan dalam menghitung pajak, maka semakin besar aset tetap yang dimiliki perusahaan mengakibatkan depresiasi yang besar juga sehingga mengakibatkan jumlah penghasilan kena pajak dan ETR nya berkurang. Hasil penelitian oleh Andhari \& Sukartha (2017) menyatakan bahwa capital intensity berpengaruh positif pada agresivitas pajak perusahaan. Hasil penelitian Putri \& Lautania (2016) juga menemukan bahwa capital intensity berpengaruh positif signifikan terhadap tarif pajak efektif. Maka berdasarkan uraian, hipotesis dirumuskan,

$\mathrm{H}_{1}$ : Capital intensity berpengaruh positif pada agresivitas pajak.

Teori keagenan menyebabkan ada konflik kepentingan yang di antara pemegang saham (prinsipal) dengan manajer perusahaan (agen), sehingga terdapat kemungkinan manajer melakukan tindakan yang dapat meningkatkan kesejahteraan dirinya sendiri dengan mengorbankan beberapa kepentingan pemegang saham, dalam hal ini kaitan dengan perilaku agresivitas pajak. Agresivitas pajak dapat dilakukan melalui mekanisme yang digolongkan tax evasion atau tax avoidance (Frank et al., 2009). Pengurangan pajak berupa tax evasion bersifat ilegal dan dapat mempengaruhi masa depan perusahaan. Salah satu metode yang dapat digunakan untuk menghilangkan permasalahan agensi yang dapat menyelaraskan kepentingan antara manajemen dengan pemegang saham, yaitu dengan meningkatkan kepemilikan saham oleh manajer pada perusahaan (Atari et al., 2016). Semakin besar proporsi kepemilikan saham manajerial di dalam perusahaan, maka pihak manajemen cenderung lebih giat untuk memperhatikan kepentingan pemegang saham dan membuat risiko perusahaan semakin kecil. Hal ini dikarenakan apabila terdapat keputusan yang salah, manajemen baik secara langsung maupun tidak langsung akan 
menanggung konsekuensinya dengan saham saham yang diinvestasikan di dalam perusahaan (Wijaya \& Saebani, 2019). Adanya kepemilikan manajerial diharapkan akan mampu mengurangi tindakan agresif manajemen dalam meminimalkan beban pajak yang ditanggung oleh perusahaan. Kepemilikan oleh manajemen dirasa mampu meningkatkan rasa memiliki oleh manajemen, sehingga akan meningkatkan perhatian pada masa depan perusahaan. Maka berdasarkan uraian, hipotesis dirumuskan,

$\mathrm{H}_{2}$ : Kepemilikan manajerial mampu memperlemah pengaruh capital intensity pada agresivitas pajak.

Konsep penelitian merupakan hubungan logis dari landasan teori yang telah dijabarkan. Konsep penelitian tersaji pada Gambar 2.

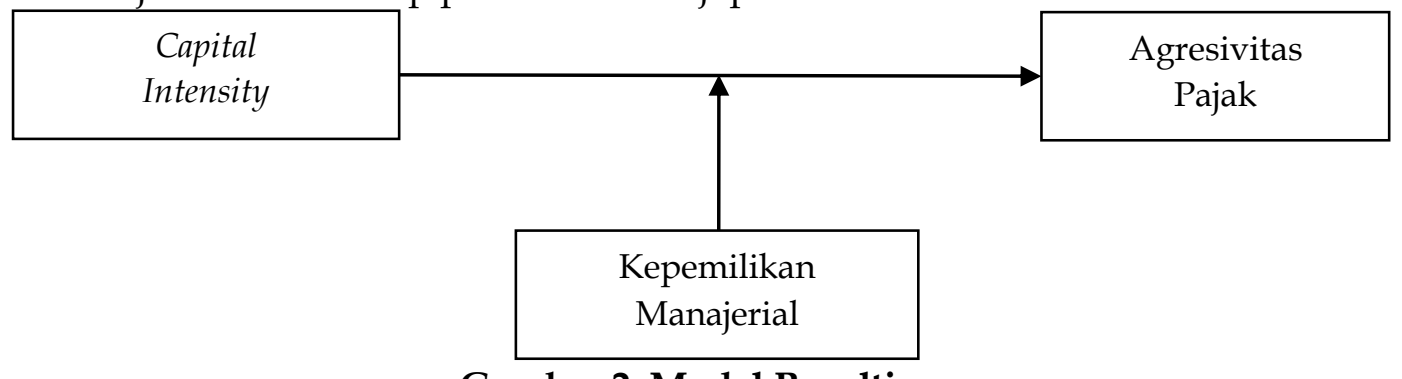

Sumber: Data Penelitian, 2020

\section{METODE PENELITIAN}

Objek penelitian adalah agresivitas pajak, populasi sebanyak 38 perusahaan manufaktur sektor industri barang konsumsi yang terdaftar di Bursa Efek Indonesia periode 2014-2018. Metode pengumpulan data yang digunakan adalah dengan metode dokumentasi di mana dalam penelitian ini memperoleh data dari men-download laporan keuangan perusahaan manufaktur sektor industri barang konsumsi yang terdaftar di Bursa Efek Indonesia (BEI) periode 2014-2018 di web resmi Bursa Efek Indonesia (BEI) www.idx.co.id.

Teknik pengambilan sampel dilakukan secara sampling bertujuan (purposive sampling). Variabel dependen dalam penelitian ini adalah agresivitas pajak. Agresivitas pajak ialah tindakan yang bertujuan untuk mengurangi pendapatan kena pajak melalui perencanaan pajak serta menggunakan metode yang diklasifikasikan atau tidak diklasifikasikan sebagai tax evasion (Frank et al., 2009). Agresivitas pajak yang diukur menggunakan Effective Tax Rate (ETR) yang mengacu pada penelitian Putri \& Lautania (2016).

Adapun rumus untuk menghitung ETR adalah sebagai berikut.

ETR $=\underline{\text { Total Beban Pajak Penghasilan }}$

Laba Sebelum Pajak

Variabel independen dalam penelitian ini adalah capital intensity. Capital intensity adalah aktivitas investasi yang dilakukan perusahaan yang dikaitkan dengan investasi dalam bentuk aset tetap (Ardyansah \& Zulaikha, 2014). Capital Intensity dapat dirumuskan sebagai berikut (Noor et al., 2010).

$\mathrm{CAP}=\underline{\text { Total Aset Tetap Bersih }}$

Total Aset 
Variabel moderasi dalam penelitian ini adalah kepemilikan manajerial. Kepemilikan manajerial adalah kepemilikan saham suatu perusahaan yang dimiliki oleh pihak manajemen (Musyarrofah \& Amanah, 2017). Rumus untuk menghitung kepemilikan manajerial merujuk dari penelitian Yetri et al. (2020) adalah sebagai berikut.

$\mathrm{KM}=$ Jumlah saham yang dimiliki direksi dan komisaris

Total saham yang beredar

Penelitian ini menggunakan metode analisis data Regresi Linier dan Moderated Regression Analysis (MRA) dengan bantuan aplikasi stastistik SPSS for Windows. Model regresi linier dalam penelitian ini, dinyatakan dengan persamaan sebagai berikut.

$Y=\alpha+\beta_{1} X_{1}+\varepsilon$

Keterangan:

$Y \quad=$ Agresivitas Pajak

a $\quad=$ Konstanta

$\mathrm{X}_{1} \quad=$ Capital Intensity

$\beta_{1} \quad=$ Koefisien regresi

$\varepsilon \quad=$ Error

Model Moderated Regression Analysis (MRA) dalam penelitian ini, dinyatakan dengan persamaan sebagai berikut.

$Y=\alpha+\beta_{1} X_{1}++\beta_{2} X_{2}++\beta_{3} X_{1} X_{2}+\varepsilon$

Keterangan:

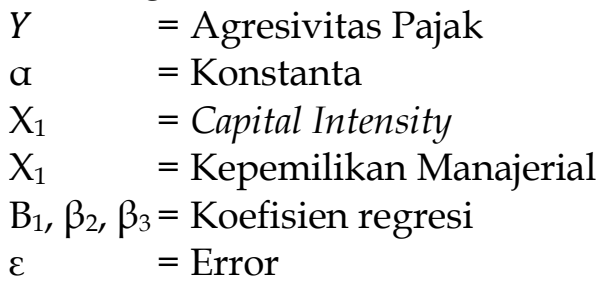

\section{HASIL DAN PEMBAHASAN}

Penelitian ini dilakukan untuk menguji pengaruh capital intensity pada agresivitas pajak. Selain itu penelitian ini juga menguji kemampuan kepemilikan manajerial dalam memoderasi pengaruh capital intensity pada agresivitas pajak Wilayah penelitian ini adalah perusahaan manufaktur sektor barang konsumsi yang terdaftar di Bursa Efek Indonesia (BEI). Sampel yang dianalisis dalam penelitian ini adalah perusahaan publik atau yang terdaftar di Bursa Efek Indonesia (BEI) periode 2014 hingga 2018. Sampel penelitian ditentukan menggunakan purposive sampling.

Berdasarkan data sekunder yang diperoleh dan diseleksi sesuai dengan kriteria yang sudah ditentukan, maka diperoleh sampel sebanyak 34 perusahaan dengan waktu pengamatan lima tahun. Adapun proses seleksi sampel disajikan pada Tabel 2.

Deskripsi variabel penelitian memberikan informasi mengenai karakteristik variabel-variabel penelitian yang terdiri atas jumlah sampel, nilai minimum, nilai maksimum, nilai rata-rata, dan standar deviasi. 
Tabel 2. Proses Penentuan Sampel Penelitian

\begin{tabular}{|c|c|c|}
\hline No. & Kriteria Sampel & Jumlah \\
\hline 1. & $\begin{array}{l}\text { Perusahaan manufaktur sektor barang konsumsi yang } \\
\text { terdaftar di Bursa Efek Indonesia pada tahun pengamatan } \\
\text { 2014-2018. }\end{array}$ & 190 \\
\hline 2. & $\begin{array}{l}\text { Perusahaan manufaktur sektor barang konsumsi yang } \\
\text { memeroleh rugi fiskal dan komersial pada tahun pengamatan } \\
\text { 2014-2018. }\end{array}$ & (29) \\
\hline \multirow[t]{3}{*}{3.} & $\begin{array}{l}\text { Perusahaan yang tidak memiliki kelengkapan informasi yang } \\
\text { dibutuhkan terkait dengan indikator-indikator }\end{array}$ & (83) \\
\hline & Data Outlier & (44) \\
\hline & Total sampel penelitian & 34 \\
\hline
\end{tabular}

Sumber: Data Penelitian, 2020

Tabel 3. menyajikan hasil uji statistik deskriptif data yang menjadi variabel penelitian.

Tabel 3. Hasil Uji Statistik Deskriptif

\begin{tabular}{lcccc}
\hline \multicolumn{1}{c}{ Variabel } & $\begin{array}{c}\text { Nilai } \\
\text { Minimum }\end{array}$ & $\begin{array}{c}\text { Nilai } \\
\text { Maksimum }\end{array}$ & $\begin{array}{c}\text { Nilai Rata- } \\
\text { rata }\end{array}$ & $\begin{array}{c}\text { Standar } \\
\text { Deviasi }\end{array}$ \\
\hline Agresivitas Pajak & 0,2912 & 0,8929 & 0,5897 & 0,1583 \\
Capital Intensity & 0,1264 & 0,3682 & 0,2408 & 0,4000 \\
Kepemilikan Manajerial & 0,0001 & 0,1154 & 0,1572 & 0,2264 \\
\hline
\end{tabular}

Sumber: Data Penelitian, 2020

Agresivitas pajak memiliki nilai minimum sebesar 0,2912 dan nilai maksimum sebesar 0,8929. Nilai rata-rata agresivitas pajak sebesar 0,5897 mempunyai arti bahwa rata-rata persentase beban pajak penghasilan dari laba sebelum pajak penghasilan perusahaan sebesar 58,97 persen. Nilai standar deviasi agresivitas pajak sebesar 0,1583 menunjukkan bahwa terjadi perbedaan nilai agresivitas pajak yang diteliti terhadap nilai rata-ratanya sebesar 0,1583.

Capital intensity memiliki nilai minimum sebesar 0,1264 dan nilai maksimum sebesar 0,3682. Nilai rata-rata capital intensity sebesar 0,2408 mempunyai arti bahwa rata-rata persentase total aset tetap bersih dari total aset perusahaan sebesar 24,08 persen. Nilai standar deviasi capital intensity sebesar 0,4000 menunjukkan bahwa terjadi perbedaan nilai capital intensity yang diteliti terhadap nilai rata-ratanya sebesar 0,4000 .

Kepemilikan manajerial memiliki nilai minimum sebesar 0,0001 dan nilai maksimum sebesar 0,1154. Nilai rata-rata kepemilikan manajerial sebesar 0,1572 mempunyai arti bahwa rata-rata persentase saham yang dimiliki oleh komisaris dan direktur di dalam suatu perusahaan sebesar 15,72 persen. Nilai standar deviasi kepemilikan manajerial sebesar 0,2264 menunjukkan bahwa terjadi perbedaan nilai kepemilikan manajerial yang diteliti terhadap nilai rata-ratanya sebesar 22,64 persen.

Sebelum melakukan pengujian hipotesis, model yang digunakan harus lolos uji asumsi klasik terlebih dahulu. Pengujian asumsi klasik meliputi uji normalitas, uji autokorelasi, uji multikolinearitas, dan uji heteroskedastisitas. Uji normalitas bertujuan untuk menguji apakah dalam residual dari model regresi yang dibuat berdistribusi normal atau tidak. Uji normalitas dalam penelitian ini menggunakan metode kolmogorov-smirnov. Hasil uji normalitas KolmogorovSmirnov menunjukkan bahwa berdasarkan Sig. (2-tailed), dapat dilihat bahwa 
Asymp.Sig. (2-tailed) pada pengujian regresi linear $(0,226)$ dan pengujian regresi moderasi $(0,118)>$ dari level of significant $(0,050)$, sehingga dapat disimpulkan bahwa variabel agresivitas pajak, capital intensity, dan kepemilikan manajerial berdistribusi normal. Uji multikolinieritas dalam penelitian ini digunakan pada regresi linear yang bertujuan untuk melihat nilai tolerance atau Variance Inflation Factor (VIF). Jika tolerance lebih dari $10 \%$ atau VIF kurang dari 10 maka dikatakan tidak ada multikolinearitas. Nilai VIF variabel di bawah 10 dan nilai tolerance di atas 0,10 sehingga dapat disimpulkan bahwa tidak terjadi hubungan multikolinieritas antar variabel bebas. Uji autokorelasi bertujuan untuk menguji adanya pengaruh data dari pengamatan sebelumnya dalam model regresi. Untuk mendeteksi ada tidaknya autokorelasi dilakukan alat analisis DurbinWatson. Hasil pengujian heteroskedastisitas menunjukkan nilai probabilitas signifikansi masing-masing variabel bebas lebih dari 0,050 sehingga dapat disimpulkan bahwa model regresi dalam penelitian ini bebas dari heteroskedastisitas.

Tabel 4, menunjukkan hasil pengujian goodness of fit dengan signifikansi sebesar 5 persen.

Tabel 4. Hasil Uji Goodness of Fit

\begin{tabular}{ccc}
\hline Uji Regresi & Sig. F & Adjusted $R$ Square \\
\hline Regresi Linear & 0,035 & 0,105 \\
Regresi Moderasi & 0,002 & 0,323 \\
\hline
\end{tabular}

Sumber: Data Penelitian, 2020

Tabel 4, menunjukkan bahwa nilai signifikansi $\mathrm{F}$ untuk uji regresi linear sebesar 0,035 lebih kecil dari $\alpha=0,050$ yang berarti model yang digunakan dalam penelitian ini telah layak (fit). Hal ini menunjukkan bahwa capital intensity mampu memprediksi atau menjelaskan agresivitas pajak yang dilakukan perusahaan manufaktur sektor barang konsumsi yang terdaftar di Bursa Efek Indonesia periode 2014 - 2018. Uji regresi linear dengan nilai Adjusted $R$ Square sebesar 0,105 mempunyai arti bahwa 10,5 persen variasi dari agresivitas pajak dipengaruhi oleh variasi capital intensity, sedangkan 89,5 persen dijelaskan oleh variabel-variabel lain di luar penelitian.

Nilai signifikansi F regresi moderasi (MRA) sebesar 0,002 lebih kecil dari $a=0,05$, yang berarti bahwa model yang digunakan dalam penelitian ini telah layak (fit). Besarnya nilai Adjusted $R$ Square adalah 0,323. Hal tersebut menunjukkan bahwa variabilitas agresivitas pajak dapat dijelaskan oleh capital intensity dan kepemilikan manajerial sebesar 32,3 persen, sedangkan sisanya sebesar 67,7 persen dijelaskan oleh variabel-variabel lain di luar model penelitian.

Tabel 5, menunjukkan hasil pengujian regresi linear dengan signifikansi sebesar 5 persen.

Tabel 5. Hasil Uji Regresi Linier

\begin{tabular}{lcc}
\hline \multicolumn{1}{c}{ Keterangan } & Nilai Beta & Signifikansi \\
\hline (Constant) & 0,187 & 0,000 \\
Capital Intensity & 0,092 & 0,035 \\
\hline Sumbr
\end{tabular}

Sumber: Data Penelitian, 2020

Hipotesis pertama menyatakan bahwa capital intensity berpengaruh positif pada agresivitas pajak. Tabel 5, menunjukkan bahwa hubungan antara 
capital intensity pada agresivitas pajak adalah sebesar 0,092 dengan nilai signifikansi 0,035 lebih kecil dari a = 0,05 yang berarti bahwa secara langsung capital intensity berpengaruh positif pada agresivitas pajak. Berdasarkan hasil penelitian tersebut maka hipotesis pertama diterima.

Hasil penelitian menunjukkan bahwa capital intensity berpengaruh positif pada agresivitas pajak. Hasil ini membuktikan Hipotesis 1 yang menyatakan bahwa capital intensity berpengaruh positif pada agresivitas pajak. Hal ini berarti semakin tinggi capital intensity menyebabkan agresivitas pajak semakin meningkat dan semakin rendah capital intensity menyebabkan agresivitas pajak semakin menurun. Investasi perusahaan pada aset tetap dapat meningkatkan beban depresiasi, sehingga dapat menjadi pilihan melakukan agresivitas pajak.

Teori akuntansi positif memaparkan perilaku manajemen perusahaan dalam pembuatan laporan keuangan terkait penggunaan dari kebijakan akuntansi tergantung pada relatif biaya, dan manfaat dari prosedur yang dipilih guna memaksimalkan fungsi mereka (Andhari \& Sukartha, 2017). Pembayaran pajak yang sesuai dengan ketentuan tentunya akan bertentangan dengan tujuan utama perusahaan, yaitu memaksimalkan keuntungan atau laba, sehingga perusahaan berusaha untuk meminimalkan biaya pajak yang ditanggungnya (Ardyansah \& Zulaikha, 2014) dan (Indradi, 2018). Salah satu cara untuk melakukan praktik agresivitas pajak adalah berinvestasi pada aset tetap (capital intensity) (Andhari \& Sukartha, 2017). Hasil penelitian ini sesuai dengan hasil penelitian yang dilakukan oleh Andhari \& Sukartha (2017) menyatakan bahwa capital intensity berpengaruh positif pada agresivitas pajak perusahaan. Senada pula dengan hasil penelitian Putri \& Lautania (2016) juga menemukan bahwa capital intensity berpengaruh positif signifikan terhadap tarif pajak efektif.

Pengujian hipotesis kedua dilakukan dengan Moderated Regression Analysis (MRA). Hasil pengujian dapat dilihat pada Tabel 6, sebagai berikut.

Tabel 6. Hasil Uji Regresi Moderasi

\begin{tabular}{lccc}
\hline \multicolumn{1}{c}{ Model } & Nilai Beta & Signifikansii & Keterangan \\
\hline (Constant) & 0,237 & 0,000 & \\
Capital Intensity & 0,014 & 0,743 & \\
Kepemilikan Manajerial & $-4,322$ & 0,005 & $\begin{array}{c}\text { Mampu } \\
\text { Interaksi antara Capital Intensity dan }\end{array}$ \\
$\begin{array}{l}\text { Kepemilikan Manajerial } \\
\text { ah }\end{array}$ \\
\hline
\end{tabular}

Sumber: Data Penelitian, 2020

Hipotesis kedua menyatakan bahwa kepemilikan manajerial memperlemah pengaruh capital intensity pada agresivitas pajak. Dilihat dari nilai signifikansi interaksi capital intensity dan kepemilikan manajerial sebesar 0,002 lebih kecil dari $a=0,05$ menunjukkan bahwa kepemilikan manajerial mampu memoderasi pengaruh capital intensity pada agresivitas pajak. Nilai beta interaksi capital intensity dan kepemilikan manajerial yang bernilai 5,854 menunjukkan bahwa kepemilikan manajerial memperlemah pengaruh capital intensity pada agresivitas pajak, maka dari itu hipotesis kedua diterima.

Hubungan variabel kepemilikan manajerial dengan variabel dependen dapat dilihat dari nilai signifikansi variabel kepemilikan manajerial sebesar 0,005, lebih kecil dari $a=0,05$. Sedangkan interaksi variabel kepemilikan manajerial 
dengan variabel independen dapat dilihat dari nilai signifikansi interaksi variabel capital intensity dengan variabel kepemilikan manajerial yaitu sebesar 0,002 , lebih kecil dari $a=0,05$. Dengan memperhatikan pengaruh langsung variabel moderasi dengan variabel dependen, dan interaksi antara variabel independen dengan variabel moderasi, maka variabel kepemilikan manajerial digolongkan ke dalam jenis moderasi semu atau quasi moderator. Quasi moderasi merupakan variabel moderasi yang berhubungan dengan variabel dependen dan atau independen serta berinteraksi dengan variabel independen (Ghozali, 2012: 224).

Hasil penelitian ini membuktikan bahwa kepemilikan manajerial memperlemah pengaruh capital intensity pada agresivitas pajak. Capital intensity yang semakin tinggi menyebabkan praktik agresivitas pajak yang semakin tinggi dan adanya kepemilikan manajerial sebagai pemegang saham mampu mengurangi perilaku manajer yang oportunis karena rasa memiliki pada perusahaan akibat kepemilikan saham direksi dan komisaris pada perusahaan, sehingga akan semakin mengurangi agresivitas pajak.

Teori keagenan menyebabkan ada konflik kepentingan yang di antara pemegang saham (prinsipal) dengan manajer perusahaan (agen), sehingga terdapat kemungkinan manajer melakukan tindakan yang dapat meningkatkan kesejahteraan dirinya sendiri dengan mengorbankan beberapa kepentingan pemegang saham, dalam hal ini kaitan dengan perilaku agresivitas pajak. Agresivitas pajak dapat dilakukan melalui mekanisme yang digolongkan tax evasion atau tax avoidance (Frank et al., 2009). Pengurangan pajak berupa tax evasion bersifat ilegal dan dapat mempengaruhi masa depan perusahaan.

Kepemilikan manajerial dapat menjadi salah satu metode yang dapat digunakan untuk menghilangkan permasalahan agensi. Kepemilikan manajerial dapat menyelaraskan kepentingan antara manajemen dengan pemegang saham (Atari et al., 2016). Hasil penelitian ini menunjukkan bahwa adanya kepemilikan manajerial mampu mengurangi tindakan agresif manajemen dalam meminimalkan biaya pajak yang dilakukan secara ilegal yang akan membahayakan masa depan perusahaan. Kepemilikan oleh manajemen dirasa mampu meningkatkan rasa memiliki oleh manajemen, sehingga akan meningkatkan perhatian pada masa depan perusahaan.

\section{SIMPULAN}

Berdasarkan hasil dan pembahasan, maka dapat disimpulkan bahwa capital intensity berpengaruh positif pada agresivitas laba. Hal tersebut menunjukkan semakin tinggi capital intensity menyebabkan agresivitas pajak juga akan semakin tinggi. Kepemilikan manajerial memperlemah pengaruh capital intensity pada agresivitas pajak. Capital intensity yang semakin tinggi menyebabkan agresivitas pajak juga semakin tinggi, adanya kepemilikan manajerial akan mengurangi agresivitas pajak. Dari penelitian ini, dapat disarankan bahwa di dalam struktur permodalan perusahaan agar mempertimbangkan adanya kepemilikan manajerial karena keberadaan kepemilikan manajerial ini dapat menjadi salah satu cara untuk mengurangi asimetri informasi di antara manajemen dengan pemegang saham. Selain itu, kepemilikan manajerial dapat mengurangi agresivitas pajak yang dilakukan oleh manajemen karena manajemen merasa 
ikut memiliki perusahaan, sehingga manajemen ikut memperhatikan masa depan perusahaan pula.

\section{REFERENSI}

Andhari, P. A. S., \& Sukartha, I. M. (2017). Pengaruh Pengungkapan Corporate Social Responsibility, Profitabilitas, Inventory Intensity, Capital Intensity, Dan Leverage Pada Agresivitas Pajak. E-Jurnal Akuntansi Universitas Udayana, 18(3), 2115-2142

Ardyansah, D., \& Zulaikha. (2014). Pengaruh Size, Leverage, Profitability, Capital Intensity Ratio dan Komisaris Independen Terhadap Effective Tax Rate (ETR). Diponegoro Journal of Accounting, 3(2), 1-9.

Atari, J., Nasir, A., \& Ilham, E. (2016). Pengaruh Kepemilikan Manajerial, Kepemilikan Institusional, dan Kebijakan Hutang Terhadap Tax Aggressive. Jurnal Online Mahasiswa Fakultas Ekonomi Universitas Riau, 3(1), 1137-1149.

Fadhila, N. S., Pratomo, D., \& Yudowati, S. P. (2017). Pengaruh Kepemilikan Manajerial, Komisaris Independen dan Komite Audit Terhadap Tax Avoidance. E-Jurnal Akuntansi Universitas Udayana, 21(3), 1803-1820. https://doi.org/10.24843/EJA.2017.v21.i03.p04

Frank, M. margaret, Lynch, L. J., \& Rego, S. O. (2009). Tax Reporting Aggressiveness and Its Relation Financial Reporting. Accounting Review, 84(2), 467-496.

Ghozali, I. (2012). Aplikasi Analisis Multivariate dengan Program IBM SPSS20. Semarang: Badan Penerbit Universitas Diponegoro.

Hanum, H. R., \& Zulaikha. (2013). Pengaruh Karakteristik Perusahaan Corporate Governance Terhadap Effective Tax Rate. Diponegoro Journal of Accounting, 2(2), 1-10.

Hartadinata, O. S., \& Tjaraka, H. (2013). Analisis Pengaruh Kepemilikan Manajerial, Kebijakan Hutang, dan Ukuran Perusahaan Terhadap Tax Aggressiveness Pada Perusahaan Manufaktur di Bursa Efek Indonesia Periode 2008 - 2010. Journal Ekonomi Dan Bisnis, XXIII(1), 48-59. https://doi.org/10.1017/CBO9781107415324.004

Indradi, D. (2018). Pengaruh Likuiditas, Capital Intensity Terhadap Agresivitas Pajak (Studi Empiris Perusahan Manufaktur Sub Sektor Industri Dasar dan Kimia Yang Terdaftar di BEI Tahun 2012-2016). Jurnal Akuntansi Berkelanjutan Indonesia, 1(1), 147-167. https://doi.org/10.32493/jabi.v1i1.y2018.p147-167

Kandaka, \& Pratiwi, R. (2019). Pengaruh Komite Audit, Leverage, dan Profitabilitas Terhadap Agresivitas Pajak ( Studi Pada Perusahaan Sektor Industri Barang Konsumsi Yang Terdaftar Di Bursa Efek Indonesia Periode 2014-2017 ). STIE Multi Data Palembang, 3(4), 56-73.

Kementerian Keuangan Republik Indonesia. (2019a). Laporan Kinerja Direktorat Jenderal Pajak (Issue 021). https:// stats.pajak.go.id/sites/default/files/202002/LAKIN DJP 2019.pdf

Kementerian Keuangan Republik Indonesia. (2019b). Media Keuangan Transparansi Informasi Kebijakan Fiskal: Vol. XIV (Issue 138).

Lanis, R., \& Richardson, G. (2011). The Effect of Board of Director Composition on Corporate Tax Aggressiveness. Journal of Accounting and Public Policy, 
30(1), 50-70. https:// doi.org/10.1016/j.jaccpubpol.2010.09.003

Lestari, P. A. S., Pratomo, D., \& Asalam, A. G. (2019). Pengaruh Koneksi Politik dan Capital Intensity Terhadap Agresivitas Pajak. Jurnal ASET (Akuntansi Riset), 11(1), 41-54.

Musyarrofah, E., \& Amanah, L. (2017). Pengaruh Kepemilikan Manajerial, Leverage, dan Size Terhadap Cash Effective Tax Rate. Jurnal Ilmu Dan Riset Akuntansi, 6(9), 1-16

Noor, R. M., Fadzillah, N. S. M., \& Mastuki, N. (2010). Corporate Tax Planning: A Study On Corporate Effective Tax Rates of Malaysian Listed Companies. International Journal of Trade, Economics and Finance, 1(2), 189-193. https://doi.org/10.7763/ijtef.2010.v1.34

Nugraha, N. B., \& Meiranto, W. (2015). Pengaruh Corporate Social Responsibility, Ukuran Perusahaan, Profitabilitas, Leverage dan Capital Intensity Terhadap Agresivitas Pajak. Diponegoro Journal of Accounting, 4(4), 1-14.

Putri, C. L., \& Lautania, M. F. (2016). Pengaruh Capital Intensity Ratio, Inventory Intensity Ratio, Ownership Structure, dan Profitability Terhadap Effective Tax Rate (ETR). Jurnal Ilmiah Mahasiswa Ekonomi Akuntansi (JIMEKA), 1(1), 101-119.

Sari, D. K., \& Martani, D. (2010). Ownership Characteristics,Corporate Governance and Tax Aggressiveness. Bridging the Gap between Theory, Research and Practice:IFRS Convergence and Application, 1-33. http://staff.ui.ac.id/system/files/users/martani/publication/tax-

03ownershipcharacteristicscorporategove-dewikartikasaridwimartani.pdf

Wijaya, D., \& Saebani, A. (2019). Pengaruh Pengungkapan Corporate Social Responsibility, Leverage, Dan Kepemilikan Manajerial Terhadap Agresivitas Pajak. Widyakala Journal, 6(1), 55-76. https://doi.org/10.36262/widyakala.v6i1.147

Yetri, E., Haryadi, \& Ilham. (2020). Pengaruh Good Corporate Governance dan Nilai Perusahaan Terhadap Tax Avoidance. Jurnal Akuntansi Dan Keuangan Universitas Jambi, 5(1), 13-20. https://doi.org/10.1108/AJAR-2016-01-01B004 